\title{
Urology - a specialty that will be faced by all future doctors
}

This article was published in the following Dove Press journal:

Advances in Medical Education and Practice

28 January 2016

Number of times this article has been viewed

\author{
Saiful Miah' \\ Karl H Pang ${ }^{2}$ \\ 'Department of Urology, Royal \\ Hallamshire Hospital, ${ }^{2}$ Academic \\ Urology Unit, School of Medicine and \\ Biomedical Sciences at the University \\ of Sheffield, Sheffield, UK
}

\section{Dear editor}

We read with great interest the articles by Shah, and Ah-kee and Khan regarding the various potential methods that could increase the exposure of undergraduate medical students to smaller specialties. ${ }^{1,2}$ We would like to draw attention to a small but high clinical volume specialty, ie, urology.

Currently in the UK, undergraduate exposure to urology is not compulsory with fewer than half of UK medical schools offering a formal placement with a urological team. ${ }^{3}$ This is particularly concerning as it has been brought to attention that urological emergencies account for more than $20 \%$ of all acute surgical admissions and $5 \%-10 \%$ of general practitioner visits. ${ }^{4}$ Urethral catheterization is a competency required in nearly all medical specialties. The General Medical Council publications Tomorrow's Doctors and The Trainee Doctor have stated that male and female catheterization are included as practical procedures that all graduates and newly qualified doctors must be able to perform. ${ }^{5,6}$

Urologists in the UK have highlighted the lack of urological exposure among undergraduate students and voiced their concerns. ${ }^{7}$ Newly qualified doctors have concurred this sentiment as only $9.7 \%$ of UK foundation trainees deemed that their undergraduate exposure to urology was of an adequate nature. ${ }^{8}$ These concerns have been raised at an international level by many countries including the US and Canada. ${ }^{9,10}$

The British Association of Urological Surgeons, the largest governing body of urological surgeons within the UK, has agreed on an undergraduate syllabus for urology. This was designed to guide and educate undergraduates on common clinical areas that are generic for the majority of practicing doctors faced with acute and non-acute urological scenarios. Within the UK, the delivery of this syllabus has been achieved with a dedicated 2-week program that also includes medical students gaining competencies in core urological skills such as male and female urethral catheterization and digital rectal examination. ${ }^{4}$ Similarly, the urological community in North America is in the process of creating a unified national curriculum to include urology at undergraduate level. ${ }^{9}$ Employing these resources for urology could be one such strategy to expose the students to relevant topics only, in a streamlined and standardized manner.

We appreciate that implementing dedicated teaching time for smaller specialties in an already overcrowded medical curriculum would be at the opportunity cost of core specialty teaching. However, in our opinion, we would strongly advocate this for urology, as it is inevitable that all newly qualified doctors will face a significant
Correspondence: Saiful Miah

Department of Urology, Roya Hallamshire Hospital, Glossop Road, Sheffield SIO 2RX, UK

Email saiful_miah@hotmail.com (c) (i) (9) 2016 Miah and Pang. This work is published and licensed by Dove Medical Press Limited. The full terms of this license are available at https://www.dovepress.com/ BY NC terms.php and incorporate the Creative Commons Attribution - Non Commercial (unported, v3.0) License (http://(creativecommons.org/licenses/by-nc/3.01). By accessing the Terms. Non-commercial uses of the work are permitted without any further permission from Dove Medical Press Limited, provided the work is properly attributed. For permission for commercial use of this work, please see paragraphs 4.2 and 5 of our Terms (https://www.dovepress.com/terms.php). 
volume of urological scenarios and procedures throughout their medical and surgical placements. Furthermore, UK medical schools and postgraduate deaneries must ensure that all graduates and newly qualified doctors demonstrate the urological competencies as highlighted by the General Medical Council.

To conclude, all newly appointed UK foundation doctors will almost certainly face acute urological issues in their early careers and likely beyond. We propose that all medical schools should include, at the very least, a formal clinical attachment in this specialty. This can be justified with the almost certain encounter of urological scenarios faced by all newly qualified doctors no matter which career path they wish to pursue.

\section{Disclosure}

The authors report no conflicts of interest in this communication.

\section{References}

1. Shah S. Are curriculum changes the ideal method for increasing undergraduate exposure to tomorrow's specialties? Adv Med Educ Pract. 2015;6:153-154.

2. Ah-Kee EY, Khan AA. How can undergraduate ophthalmology teaching be improved? Adv Med Educ Pract. 2015;6:469-470.

3. Derbyshire LF, O'Flynn KJ. Medical students' exposure to urology in the undergraduate curriculum, a web based survey. BJMSU. 2012;5:4-10.

4. Miah S, Mangera A, Venugopal S, Luk A, McDermid R, Rosario D. The clinical need for undergraduate urology. Clin Teach. 2015;12(5): 353-355.

5. General Medical Council. Tomorrow's Doctors. London: GMC; 2009.

6. General Medical Council. The Trainee Doctor. London: GMC; 2011.

7. Malde S, Shrotri N. Undergraduate urology in the UK: does it prepare doctors adequately? BJMSU. 2012;5:16-19.

8. Loughlin $\mathrm{KR}^{1}$. The current status of medical student urological education in the United States. J Urol. 2008;179(3):1087-1090.

9. Hoag NA, Hamidizadeh R, MacNeily AE. Undergraduate exposure to urology: impact of the distributed model of medical education in British Columbia. Can Urol Assoc J. 2013;7(1-2):20-25.

10. Rourke K. Teaching undergraduate urology: it takes a village. Can Urol Assoc J. 2013;7(1-2):26-27.

Dove Medical Press encourages responsible, free and frank academic debate. The content of the Advances in Medical Education and Practice 'letters to the editor' section does not necessarily represent the views of Dove Medical Press, its officers, agents, employees, related entities or the Advances in Medical Education and Practice editors. While all reasonable steps have been taken to confirm the content of each letter, Dove Medical Press accepts no liability in respect of the content of any letter, nor is it responsible for the content and accuracy of any letter to the editor.

Advances in Medical Education and Practice

\section{Dovepress}

\section{Publish your work in this journal}

Advances in Medical Education and Practice is an international, peerreviewed, open access journal that aims to present and publish research on Medical Education covering medical, dental, nursing and allied health care professional education. The journal covers undergraduate education, postgraduate training and continuing medical education including emerging trends and innovative models linking education, research, and health care services. The manuscript management system is completely online and includes a very quick and fair peer-review system. Visit http://www.dovepress.com/testimonials.php to read real quotes from published authors.

Submit your manuscript here: http://www.dovepress.com/advances-in-medical-education-and-practice-journal 